\title{
EFFICACY AND SAFETY OF A SINGLE-PILL COMBINATION OF ATORVASTATIN/AMLODIPINE IN PATIENTS WITH ARTERIAL HYPERTENSION AND DYSLIPIDEMIA
}

\begin{abstract}
Stefan Naydenov Naydenov ${ }^{1}$, Nikolay Margaritov Runev ${ }^{1}$, Emil Ivanov Manov ${ }^{1}$ and Svetla Georgieva Torbova-Gigova ${ }^{2}$

${ }^{1}$ Prof. St. Kirkovich Department of Internal Diseases, Medical University of Sofia, Sofia, Bulgaria;

${ }^{2}$ Tokuda Hospital, Sofia, Bulgaria

SUMMARY - The aim was to evaluate the efficacy of a single-pill combination of atorvastatin/ amlodipine in patients with arterial hypertension, dyslipidemia and moderate to high cardiovascular risk. This prospective study included 243 patients with arterial hypertension, dyslipidemia and moderate to high cardiovascular risk, mean age $63.3 \pm 9.8$ years. All patients were prescribed a treatment with one of the following doses of a single-pill combination of atorvastatin/amlodipine: 10/5, 10/10, 20/5 or 20/10 mg daily. The follow-up period was 3 months. The mean baseline values of the systolic and diastolic blood pressure were $155.7 \pm 16.2$ and $92.0 \pm 9.2 \mathrm{~mm} \mathrm{Hg}$, respectively. At month 3 , the respective mean systolic and diastolic blood pressure values were $136.9 \pm 26.9$ and $80.6 \pm 5.1 \mathrm{~mm} \mathrm{Hg}$. The mean baseline values of total cholesterol and low-density lipoprotein cholesterol were $6.6 \pm 1.2$ and $4.4 \pm 1.1 \mathrm{mmol} / \mathrm{L}$, respectively. At month 3, the respective mean values of total cholesterol and lowdensity lipoprotein cholesterol were $5.1 \pm 0.9$ and $2.9 \pm 1.0 \mathrm{mmol} / \mathrm{L}$. Treatment was discontinued in 9 (3.7\%) patients due to adverse events. In conclusion, treatment with the single-pill combination of atorvastatin/amlodipine was effective and well tolerated by the patients with arterial hypertension, dyslipidemia and moderate to high cardiovascular risk.
\end{abstract}

Key words: Hypertension; Dyslipidemias; Cardiovascular diseases; Antibypertensive agents

\section{Introduction}

Arterial hypertension (HTN) and dyslipidemias are the most significant risk factors $(\mathrm{RF})$ for cardiovascular (CV) complications worldwide ${ }^{1-4}$. HTN affects $\sim 22 \%$ of the world population (30\%-45\% in Europe and North America) and dyslipidemias 39\% of the population aged $\geq 25$ years ( $54 \%$ of the Europeans $)^{1-5}$.

In a number of epidemiological studies, elevated blood pressure (BP) and cholesterol have been identified as strong RF for coronary heart disease, cerebro-

Correspondence to: Stefan Naydenov Naydenor, $M D, P h D$, Prof. St. Kirkovich Department of Internal Diseases, Medical University of Sofia, 1 Georgi Sofiyski Str., Sofia 1431, Bulgaria

E-mail: snaydenov@gmail.com

Received May 29, 2017, accepted December 28, 2017 vascular disease, peripheral arterial disease, etc. ${ }^{6-7}$. Regardless of the existing pharmacological and nonpharmacological options, control of these RF is unsatisfactory. At least $50 \%$ of patients with HTN and/or hypercholesterolemia in many countries of Europe, North America and Asia maintain BP and/or lowdensity lipoprotein cholesterol (LDL-C) and/or total cholesterol (TC) levels above the target ones ${ }^{1,2,7}$. Each year $\sim 8$ million hypertensives die and another $\sim 60$ million develop severe debilitating complications as a consequence of uncontrolled HTN ${ }^{5}$. Another 2.6 million patients with dyslipidemia die yearly and about 30 million are seriously disabled due to untreated or not effectively treated hypercholesterolemia ${ }^{8}$.

The contemporary combination antihypertensive and lipid-lowering strategies are based mostly on the 
level of $\mathrm{CV}$ risk of the individual patient on the one hand, and on the BP, LDL-C and TC values (baseline and target ones) on the other hand ${ }^{5,8,9}$. Where possible, single-pill combinations (SPC) are widely recommended because of the certain advantages over free combinations, i.e. standardized dose of the ingredients, facilitated treatment regimen with less tablets and often more affordable price ${ }^{5,8,11}$. These features improve patient adherence to the prescribed treatment, and thus to HTN and dyslipidemia control ${ }^{11-13}$.

The SPC of atorvastatin/amlodipine in various proportions is one the most reasonable options for combination treatment in patients with HTN and hypercholesterolemia. Its pharmacokinetic and pharmacodynamic features, as well as the proven clinical benefits of each of the active components gave us grounds for conducting a prospective clinical study among outpatients ${ }^{14-16}$.

\section{Patients and Methods}

A prospective, open-label study, conducted from March to August, 2014, included 243 consecutive outpatients with HTN and dyslipidemia (128 (52.7\%) males) from 20 Bulgarian cities, towns and villages, mean age $63.3 \pm 9.8$ (range, 40-91) years. The study conductance was in accordance with ethical standards of the institutional or regional responsible committee on human experimentation and with the Helsinki Declaration of 1975, as revised in 1983. A written informed consent was obtained from all patients before their enrolment in the study and an approval of the study was obtained from the local ethics committee.

\section{Inclusion criteria}

The study inclusion criteria were as follows: 1) patients with essential HTN and dyslipidemia (according to the current European guidelines for diagnosis and treatment of these diseases); 2) patients on outpatient antihypertensive and lipid-lowering therapy, not achieving the target $\mathrm{BP}$ and/or LDL-C values according to the current European guidelines ${ }^{5,8}$ at $\geq 1$ month of treatment initiation; 3) patients requiring antihypertensive and lipid-lowering therapy according to the current European guidelines, but not receiving medication therapy before inclusion in the study; 4) feasible follow-up in the course of 3 months after initiation of atorvastatin/amlodipine treatment; and 5) an informed consent from the patient to participate in the study.

\section{Exclusion criteria}

Exclusion criteria were as follows: 1) known secondary hypertension and/or dyslipidemia; 2) target BP and/or lipid levels achieved by the ongoing therapy; 3 ) known adverse effects from previous experience or present contraindications to any of the atorvastatin/ amlodipine SPC components; 4) patients already on maximal daily dose of amlodipine (10 mg) and/or atorvastatin $(80 \mathrm{mg})$, not achieving the target $\mathrm{BP}$ and/ or lipid levels; 5) patient's refusal to be treated with the atorvastatin/amlodipine SPC; and 6) impossibility of patient follow-up in the course of 3 months for whatever reason.

Among all patients, 231 (95.1\%) had antihypertensive treatment, but had not achieved the target BP values despite combination therapy with 2 to 3 drugs in most of them (218 of 231, 94.4\%). An angiotensinconverting enzyme inhibitor had been included in therapy of 118 (48.6\%) patients, a calcium channel blocker was taken by 81 (33.3\%), an angiotensin IIreceptor blocker by 88 (36.2\%), a beta-blocker by 152 (62.6\%), a thiazide diuretic by 19 (7.8\%), and other BP-lowering drugs by 28 (11.5\%) patients. The mean number of antihypertensive tablets received by the hypertensive patients was $3.0 \pm 1.5(0-8): 2$ tablets by 48 (22.0\%), 3 tablets by $77(35.3 \%), 4$ tablets by 39 (17.9\%) and 5 tablets by 25 (10.3\%) patients.

Sixty-seven $(27.6 \%)$ patients had been on statin treatment before inclusion in the study, and 31 (46.3\%) of them had received atorvastatin.

All patients were evaluated for CV risk. The Systematic COronary Risk Evaluation (SCORE) mod$\mathrm{el}^{5,8}$ was used to assess the absolute 10 -year risk of fatal cardiac event in asymptomatic patients with cardiovascular RF. The added CV risk was assessed in hypertensives with RF and/or subclinical target organ damage or overt $\mathrm{CV}$ or non-cardiac complications. The risk was found to be moderate in $70(39.3 \%)$ and high in 173 (59.7\%) patients.

All patients enrolled in our study started treatment with one of the following doses of the SPC atorvastatin/amlodipine (Gedeon Richter Plc., Hungary): $10 / 5,10 / 10,20 / 5$ or 20/10 $\mathrm{mg}$ daily with up-titration at visit 1 when necessary. The dosage was determined 


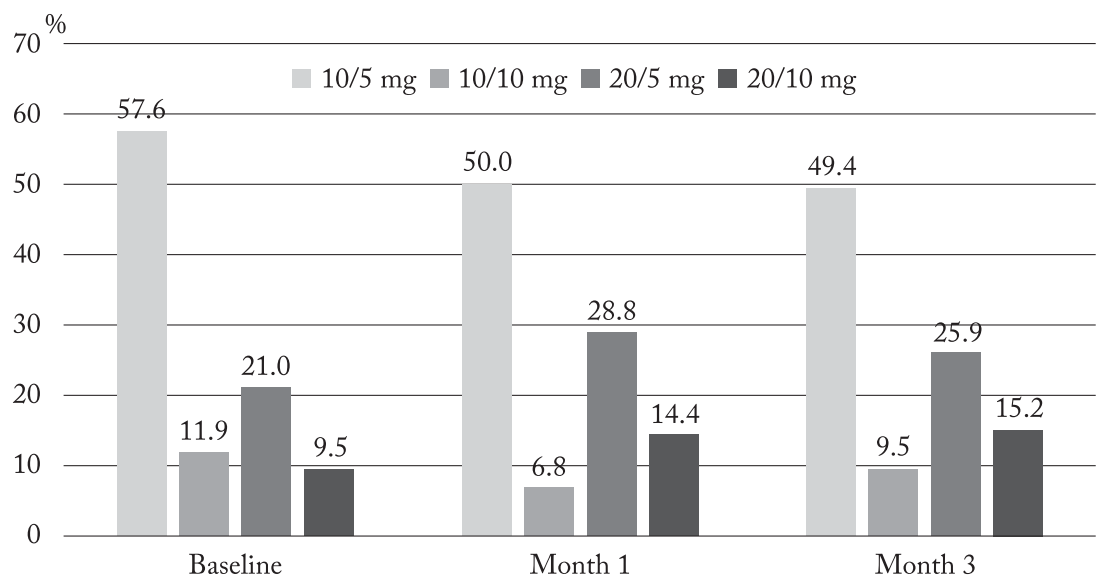

Fig. 1. Prescription of different atorvastatin/amlodipine combinations to study population at baseline, month 1 and month 3.

10/5 mg: $\mathrm{p}=0.03$ for baseline vs. month 1 and month $3 ; \mathrm{p}=\mathrm{NS}$ for month 1 vs. month 3; 10/10 mg: $\mathrm{p}=0.01$ for baseline vs. month 1 and $\mathrm{p}=0.04$ vs. month $3, \mathrm{p}=0.03$ for month 1 vs. month 3 ;

20/5 mg: $p<0.0001$ for baseline vs. month 1 and month 3; $\mathrm{p}=\mathrm{NS}$ for month 1 vs. month 3; 20/10 mg: $p=0.02$ for baseline vs. month 1 and month 3; $\mathrm{p}=\mathrm{NS}$ for month 1 vs. month 3 .

$\mathrm{NS}=$ nonsignificant; $\mathrm{p}=$ level of statistical significance

by the treating physician based on the BP and LDL-C values and the level of individual $\mathrm{CV}$ risk as well.

The concomitant medication was continued unless it was a calcium channel blocker or statin. The period of patient follow-up was 3 months with clinical visits at the end of months 1 and 3 after initiation of SPC atorvastatin/amlodipine treatment. At baseline and at each follow-up visit, office BP measurement was performed after 10-min rest in sitting position, twice at the non-dominant arm with 1-min interval between the measurements. During follow-up visits, detailed medical history was taken about treatment regimen, home BP control and presence of adverse effects (AE). In patients not achieving the target $\mathrm{BP}$ and/or LDL$\mathrm{C}$ levels recommended by the current Guidelines of the European Society of Cardiology, an increase in the dose of the researched combination was considered.

At baseline and at month 3, the following lipid parameters were examined: TC, LDL-C, high-density lipoprotein cholesterol (HDL-C) and triglycerides (TG).

\section{Statistics}

Statistical analysis was carried out with SPSS statistical package, version 16.0 (SPSS Inc, Chicago, IL, USA). Data were expressed by frequencies and percentages for categorical variables, and by minimal, maximal, mean values and standard deviation for continuous variables. Comparisons were made by using the independent $\chi^{2}$-test, $t$-test, and ANOVA. The level of statistical significance was set at $\mathrm{p}<0.05$.

\section{Results}

Figure 1 shows the prescription rate of the analyzed 4 dose combinations of atorvastatin/amlodipine at baseline, month 1 and month 3 .

The mean systolic blood pressure (SBP) and diastolic blood pressure (DBP) values of the analyzed group of patients at baseline and at the end of month 1 and 3 are shown in Table 1, whereas Figure 2 illustrates the dynamics of BP during the follow-up period.

The normalization rate of $\mathrm{BP}$, defined for our study as $\mathrm{SBP}<140$ and DBP $<90 \mathrm{~mm} \mathrm{Hg}(<85 \mathrm{~mm} \mathrm{Hg}$ for diabetic patients) in accordance with the current 2013 ESC Guidelines for treatment of arterial hypertension $^{5}$ was as follows:

- at month 1: $\mathrm{SPB}<140 \mathrm{~mm} \mathrm{Hg}$ was achieved by $147(60.5 \%)$ and DBP $<90 \mathrm{~mm} \mathrm{Hg}$ by 183 (75.3\%) patients; $\mathrm{p}<0.0001$ vs. baseline;

- at month 3: SPB $<140 \mathrm{~mm} \mathrm{Hg}$ was achieved by $175(72.1 \%)$ and DBP $<90 \mathrm{~mm} \mathrm{Hg}$ by 221 (91.0\%) patients; $\mathrm{p}<0.0001$ vs. baseline and month 1. 
Table 1. Systolic and diastolic blood pressure values in study population at baseline and at follow-up visits during the treatment period

\begin{tabular}{|c|c|c|c|c|}
\hline $\begin{array}{l}\text { Blood } \\
\text { pressure }\end{array}$ & $\begin{array}{l}\text { Minimal } \\
\text { value } \\
(\mathrm{mm} \mathrm{Hg})\end{array}$ & $\begin{array}{l}\text { Maximal } \\
\text { value } \\
(\mathrm{mm} \mathrm{Hg})\end{array}$ & $\begin{array}{l}\text { Mean } \\
\text { value } \\
(\mathrm{mm} \mathrm{Hg})\end{array}$ & $\begin{array}{l}\text { Standard } \\
\text { deviation }\end{array}$ \\
\hline $\begin{array}{l}\text { Baseline } \\
\text { SBP }\end{array}$ & 146 & 200 & 155.67 & 16.21 \\
\hline $\begin{array}{l}\text { Baseline } \\
\text { DBP }\end{array}$ & 90 & 118 & 92.03 & 9.23 \\
\hline $\begin{array}{l}\text { SBP } \\
- \text { month } 1\end{array}$ & 107 & 183 & 140.69 & 13.59 \\
\hline $\begin{array}{l}\mathrm{DBP} \\
- \text { month } 1 \\
\end{array}$ & 70 & 105 & 83.41 & 6.32 \\
\hline $\begin{array}{l}\text { SBP } \\
- \text { month } 3\end{array}$ & 112 & 148 & 136.88 & 26.97 \\
\hline $\begin{array}{l}\mathrm{DBP} \\
- \text { month } 3\end{array}$ & 65 & 90 & 80.64 & 5.07 \\
\hline
\end{tabular}

$\mathrm{DBP}$ = diastolic blood pressure; $\mathrm{SBP}$ = systolic blood pressure

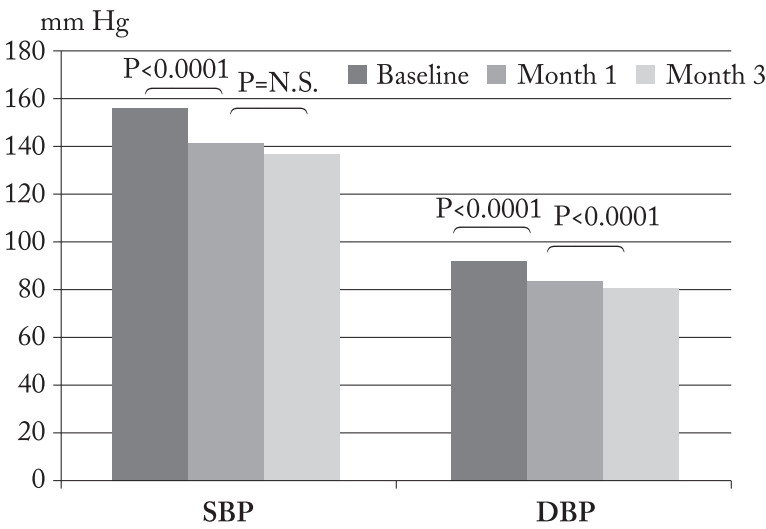

Fig. 2. Dynamics of systolic and diastolic blood pressure in study population after initiation of treatment with atorvastatin/amlodipine.

$\mathrm{DBP}$ = diastolic blood pressure; $\mathrm{SBP}=$ systolic blood pressure; NS $=$ nonsignificant $; \mathrm{p}=$ level of statistical significance

The mean SBP and DBP values of patients treated with the most frequently prescribed dosage of $10 / 5 \mathrm{mg}$ of the SPC of atorvastatin/amlodipine are shown in Table 2, whereas Figure 3 illustrates the dynamics of their BP during the follow-up period.

The normalization rate of $\mathrm{BP}$ of the patients treated with atorvastatin/amlodipine $10 / 5 \mathrm{mg}$ was as follows:

- at month 1: SPB $<140 \mathrm{~mm} \mathrm{Hg}$ was achieved by $64(45.7 \%)$ and $\mathrm{DBP}<90 \mathrm{~mm} \mathrm{Hg}$ by 116 $(82.6 \%)$ patients; $\mathrm{p}<0.0001$ vs. baseline;
Table 2. Systolic and diastolic blood pressure values in study patients treated with the lowest dose of atorvastatin/amlodipine (10/5 mg)

\begin{tabular}{|c|c|c|c|c|}
\hline $\begin{array}{l}\text { Blood } \\
\text { pressure }\end{array}$ & $\begin{array}{l}\text { Minimal } \\
\text { value } \\
(\mathrm{mm} \mathrm{Hg})\end{array}$ & $\begin{array}{l}\text { Maximal } \\
\text { value } \\
(\mathrm{mm} \mathrm{Hg})\end{array}$ & \begin{tabular}{|l} 
Mean \\
value \\
$(\mathrm{mm} \mathrm{Hg})$
\end{tabular} & $\begin{array}{l}\text { Standard } \\
\text { deviation }\end{array}$ \\
\hline $\begin{array}{l}\text { Baseline } \\
\text { SBP }\end{array}$ & 146 & 197 & 153.17 & 15.03 \\
\hline $\begin{array}{l}\text { Baseline } \\
\text { DBP }\end{array}$ & 90 & 110 & 90.81 & 9.02 \\
\hline $\begin{array}{l}\text { SBP } \\
- \text { month } 1\end{array}$ & 108 & 182 & 138.55 & 12.80 \\
\hline $\begin{array}{l}\text { DBP } \\
- \text { month } 1\end{array}$ & 70 & 95 & 82.71 & 5.59 \\
\hline $\begin{array}{l}\text { SBP } \\
- \text { month } 3\end{array}$ & 116 & 167 & 130.36 & 12.99 \\
\hline $\begin{array}{l}\text { DBP } \\
- \text { month } 3\end{array}$ & 65 & 90 & 80.59 & 5.47 \\
\hline
\end{tabular}

$\mathrm{DBP}$ = diastolic blood pressure; $\mathrm{SBP}=$ systolic blood pressure

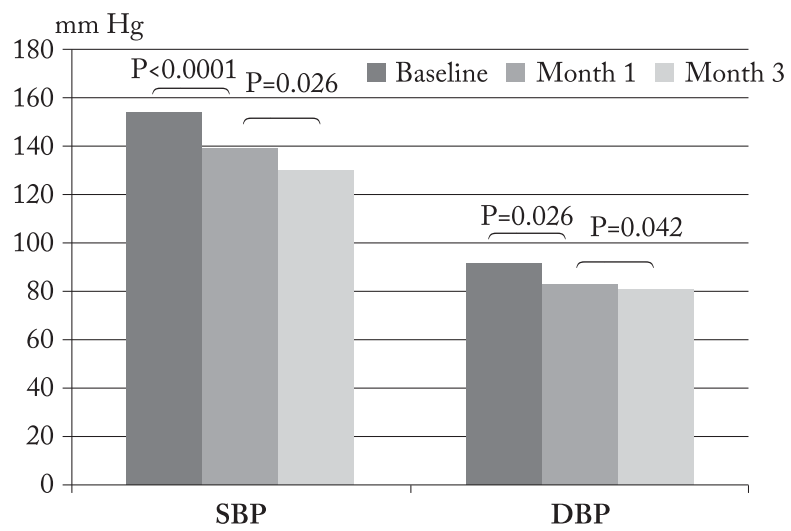

Fig. 3. Dynamics of systolic and diastolic

blood pressure in patients treated with 10/5 $\mathrm{mg}$ atorvastatin/amlodipine.

$\mathrm{DBP}=$ diastolic blood pressure; $\mathrm{SBP}=$ systolic blood pressure; $\mathrm{p}=$ level of statistical significance

- at month 3: $\mathrm{SPB}<140 \mathrm{~mm} \mathrm{Hg}$ was achieved by $108(76.9 \%)$ and DBP <90 mm Hg by 127 $(90.6 \%)$ patients, $\mathrm{p}<0.0001$ vs. baseline and month 1.

The mean values of the lipid parameters at baseline and at month 3 are shown in Table 3, whereas the dynamics of TC and LDL-C are illustrated in Figure 4.

Target values of the analyzed lipid parameters (according to the recommendations of the current 
Table 3. Values of lipid parameters in study population

\begin{tabular}{|c|c|c|c|c|}
\hline \begin{tabular}{|l|} 
Lipid \\
parameter \\
$(\mathrm{mmol} / \mathrm{L})$
\end{tabular} & $\begin{array}{l}\text { Minimal } \\
\text { value }\end{array}$ & $\begin{array}{l}\text { Maximal } \\
\text { value }\end{array}$ & $\begin{array}{l}\text { Mean } \\
\text { value }\end{array}$ & $\begin{array}{l}\text { Standard } \\
\text { deviation }\end{array}$ \\
\hline Baseline TC & 5.4 & 10.3 & 6.6 & 1.2 \\
\hline $\begin{array}{l}\text { Baseline } \\
\text { LDL-C }\end{array}$ & 3.5 & 7.9 & 4.4 & 1.1 \\
\hline $\begin{array}{l}\text { Baseline } \\
\text { HDL-C }\end{array}$ & 0.5 & 2.2 & 1.3 & 0.5 \\
\hline Baseline TG & 0.6 & 6.0 & 2.1 & 0.8 \\
\hline TC - month 3 & 2.9 & 6.4 & 5.1 & 0.9 \\
\hline $\begin{array}{l}\text { LDL-C } \\
- \text { month } 3\end{array}$ & 0.8 & 4.6 & 2.9 & 1.0 \\
\hline $\begin{array}{l}\text { HDL-C } \\
- \text { month } 3\end{array}$ & 0.8 & 2.5 & 1.4 & 0.5 \\
\hline TG - month 3 & 0.6 & 4.6 & 1.6 & 0.7 \\
\hline
\end{tabular}

HDL-C = high-density lipoprotein cholesterol; LDL-C = lowdensity lipoprotein cholesterol; $\mathrm{TC}=$ total cholesterol; $\mathrm{TG}=$ triglycerides

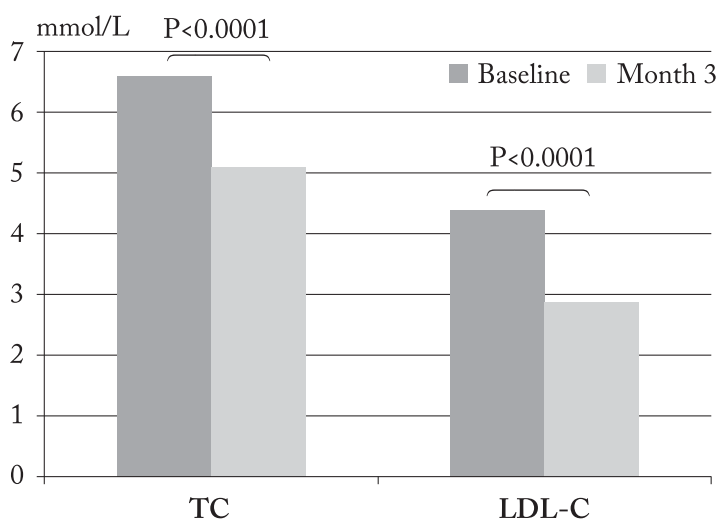

Fig. 4. Dynamics of total cholesterol and low-density lipoprotein cholesterol in study population.

$\mathrm{TC}=$ total cholesterol; LDL-C = low-density lipoprotein cholesterol; $\mathrm{p}=$ level of statistical significance

ESC Guidelines for cardiovascular prevention) ${ }^{8}$ were achieved at month 3 as follows:

- patients at moderate $\mathrm{CV}$ risk: LDL-C $<3.0$ $\mathrm{mmol} / \mathrm{L}$ in $52(74.3 \%)$ and $\mathrm{TC}<5.0 \mathrm{mmol} / \mathrm{L}$ in 55 (78.6\%) patients; $\mathrm{p}<0.0001$ vs. baseline;

- patients at high CV risk: LDL-C $<2.5 \mathrm{mmol} / \mathrm{L}$ in $108(62.4 \%)$ and TC values $<4.5 \mathrm{mmol} / \mathrm{L}$ in 114 (65.9\%) patients; $p<0.0001$ vs. baseline.

The values of lipid parameters in patients treated with the most frequently prescribed dosage of $10 / 5 \mathrm{mg}$
Table 4. Values of lipid parameters in patients treated with the lowest dose of atorvastatin/amlodipine (10/5 mg)

\begin{tabular}{|c|c|c|c|c|}
\hline \begin{tabular}{|l|} 
Lipid \\
parameter \\
$(\mathrm{mmol} / \mathrm{L})$
\end{tabular} & $\begin{array}{l}\text { Minimal } \\
\text { value }\end{array}$ & $\begin{array}{l}\text { Maximal } \\
\text { value }\end{array}$ & $\begin{array}{l}\text { Mean } \\
\text { value }\end{array}$ & $\begin{array}{l}\text { Standard } \\
\text { deviation }\end{array}$ \\
\hline Baseline TC & 5.4 & 9.7 & 6.3 & 1.2 \\
\hline $\begin{array}{l}\text { Baseline } \\
\text { LDL-C }\end{array}$ & 3.5 & 7.9 & 4.3 & 1.2 \\
\hline $\begin{array}{l}\text { Baseline } \\
\text { HDL-C }\end{array}$ & 0.5 & 1.9 & 1.3 & 0.4 \\
\hline Baseline TG & 0.6 & 3.5 & 1.9 & 0.7 \\
\hline TC - month 3 & 3.3 & 6.4 & 5.2 & 1.0 \\
\hline $\mid \begin{array}{l}\text { LDL-C } \\
- \text { month } 3\end{array}$ & 1.0 & 5.7 & 3.1 & 1.0 \\
\hline $\begin{array}{l}\text { HDL-C } \\
- \text { month } 3\end{array}$ & 0.8 & 2.1 & 1.3 & 0.4 \\
\hline TG - month 3 & 0.6 & 4.4 & 1.7 & 0.7 \\
\hline
\end{tabular}

HDL-C = high-density lipoprotein cholesterol; LDL-C = lowdensity lipoprotein cholesterol; $\mathrm{TC}=$ total cholesterol; $\mathrm{TG}=$ triglycerides

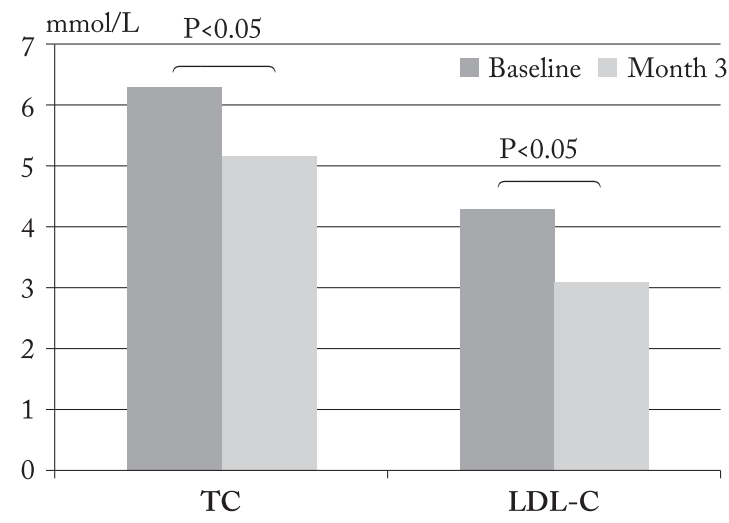

Fig. 5. Dynamics of total cholesterol and low-density lipoprotein cholesterol in patients treated with $10 / 5 \mathrm{mg}$ atorvastatin/amlodipine.

$\mathrm{TC}=$ total cholesterol; LDL-C $=$ low-density lipoprotein choles terol; $\mathrm{p}=$ level of statistical significance

of the SPC of atorvastatin/amlodipine are shown in Table 4, whereas Figure 5 shows the dynamics of TC and LDL-C.

Treatment with the lowest dose of $10 / 5 \mathrm{mg}$ of the SPC of atorvastatin/amlodipine achieved target values of the analyzed lipid parameters at month 3 as follows: 
- patients at moderate CV risk: LDL-C values $<3.0 \mathrm{mmol} / \mathrm{L}$ in $37(63.8 \%)$ and $\mathrm{TC}$ values $<5.0$ $\mathrm{mmol} / \mathrm{L}$ in $39(67.2 \%)$ patients; $\mathrm{p}<0.0001$ vs. baseline;

- patients at high $\mathrm{CV}$ risk: $\mathrm{LDL}-\mathrm{C}<2.5 \mathrm{mmol} / \mathrm{L}$ in $24(38.7 \%)$ and TC values $<4.5 \mathrm{mmol} / \mathrm{L}$ in 28 $(45.2 \%)$ patients; $\mathrm{p}<0.0001$ vs. baseline.

On clinical visits at months 1 and 3, we recorded the following adverse events (AE) that could be attributed to the treatment with the SPC of atorvastatin/amlodipine:

- mild to moderate facial flush: 2 (1.1\%) patients at month 1 and $1(0.6 \%)$ patient at month 3;

- mild to moderate swelling edema of lower extremities: $6(3.4 \%)$ patients at month 1 and month 3 each;

- mild to moderate headache: $3(1.7 \%)$ patients at month 1 , whereas none of the patients complained of headache at month 3 ;

- mild to moderate myalgia: $2(1.1 \%)$ patients at month 1 and month 3 each.

Treatment with the investigated SPC of atorvastatin/amlodipine was discontinued in nine (3.7\%) patients because of $\mathrm{AE}$ (swelling edema and/or headache); three of them stopped treatment at week 2, four patients at month 1 and two patients at month 2 .

\section{Discussion}

In our study, treatment of patients with the SPC of atorvastatin and amlodipine led to significant reduction of both blood pressure and LDL-C as important indicators of $\mathrm{CV}$ risk. The mean reduction of $\mathrm{BP}$ across all dose regimens used (from $10 / 5 \mathrm{mg}$ to $20 / 10 \mathrm{mg}$ ) was $\sim 12 \%$ for SBP and DBP each. The percentage of patients achieving the target $\mathrm{BP}$ values at the end of the study was high $(72.1 \%$ and $91.0 \%$ for SBP and DBP, respectively).

Our results were comparable to those published by Kékes $^{17}$. In their study, 2606 patients with HTN and dyslipidemia were treated with an SPC of atorvastatin and amlodipine. All dosage regimens from 10/5 to 20/10 mg were analyzed. The mean baseline SBP and DBP values were 155.9 and $90.2 \mathrm{~mm} \mathrm{Hg}$ and they were reduced at month 3 to 136.9 and $83.6 \mathrm{~mm} \mathrm{Hg}$, respectively. At the end of the study, $86.5 \%$ of the patients reached the target BP levels $(<140 / 90 \mathrm{~mm} \mathrm{Hg})^{17}$.
In our study, the analyzed SPCs also demonstrated a statistically significant lipid-lowering effect; the values of TC and LDL-C were reduced by $\sim 23 \%$ and $34 \%$, respectively, compared to baseline values. In the study performed by Kékes et al., LDL-cholesterol was reduced from the mean value of $3.45 \mathrm{mmol} / \mathrm{L}$ to 2.49 $\mathrm{mmol} / \mathrm{L}$ after 3 months of treatment and $76.4 \%$ of the patients reached the target LDL-C levels at the end of the study ${ }^{17}$.

In more than half of our patients, the lowest dosage of the SPC of atorvastatin/amlodipine was prescribed at inclusion in the study (individual decision of the treating physician) and this regimen was maintained until the end of the study in $49 \%$ of patients. This dosage achieved $15 \%$ additional SBP and $11 \%$ DBP reduction when added to the ongoing antihypertensive therapy. The mean reduction of the analyzed lipid parameters by this dosage of atorvastatin/amlodipine was by $~ 18 \%$ for TC and by $28 \%$ for LDL-C. Reduction of LDL-C $<3.0 \mathrm{mmol} / \mathrm{L}$ was achieved by $46.5 \%$ of the patients treated with the $10 / 5 \mathrm{mg}$ SPC of atorvastatin/amlodipine. It means that the low-dose combination of atorvastatin/amlodipine could be a reasonable choice for a large number of patients with moderate to high $\mathrm{CV}$ risk and mild to moderate elevation of $\mathrm{BP}$ and LDL-C.

Our results could also be compared with the results from several other studies. In the Gemini Study (1220 patients with uncontrolled HTN and dyslipidemia included), eight dosage regimens of an SPC of amlodipine/atorvastatin (from 5/10 to $10 / 80 \mathrm{mg}$ ) were electively titrated to improve blood pressure and lipid control ${ }^{18}$. At baseline, the mean BP was $146.6 / 87.9 \mathrm{~mm}$ $\mathrm{Hg}$ and mean LDL-C was $152.9 \mathrm{mg} / \mathrm{dL}$. At the end of the study, $57.7 \%$ of patients achieved both their BP and LDL-C goals. The mean dose of the study medication at the end point was amlodipine component 7.1 $\mathrm{mg}$ and atorvastatin component $26.2 \mathrm{mg}^{18}$.

In the CAPABLE clinical trial (499 patients with HTN and dyslipidemia included), the SPC of amlodipine/atorvastatin was also administered in one of the 8 dosage regimens available (from $5 / 10$ to $10 / 80 \mathrm{mg}$ ), with the dose being titrated according to the intermediate results ${ }^{19}$. At the end point, $48.3 \%$ of patients reached both their $\mathrm{BP}$ and LDL-C goals; $56.8 \%$ reached BP goals and 73.7\% reached LDL-C goals ${ }^{19}$.

Two other open-label studies conducted in 122 study centers across the United Kingdom and Canada 
(JEWEL 1) and 113 centers across 11 European countries (JEWEL 2) evaluated the clinical utility of the SPC of amlodipine plus atorvastatin to help patients across Europe and Canada achieve country-specific targets for $\mathrm{BP}$ and LDL-C ${ }^{20}$. The treatment period was 16 weeks. Among 2245 patients enrolled in these studies, 62.9\% in JEWEL 1 and 50.6\% in JEWEL 2 reached both country-specific BP and LDL-C goals. BP was reduced by 20.4/10.7 and 21.8/12.6 mm $\mathrm{Hg}$ in JEWEL 1 and JEWEL 2, respectively, and reductions in LDL-C were $0.90 \mathrm{mmol} / \mathrm{L}$ and 1.09 $\mathrm{mmol} / \mathrm{L}$, respectively ${ }^{20}$.

Our results and the reports of other clinical studies presented above are quite important. Epidemiologic data have suggested that, on average, less than $10 \%$ of patients with concomitant hypertension and dyslipidemia are at target levels for both conditions ${ }^{7,21}$. The large benefits that can result from simultaneous treatment of hypertension and dyslipidemia and the current suboptimal management of these conditions worldwide demonstrate that novel solutions are needed to treat the growing number of patients who have both of these important CV risk factors. The SPC of amlodipine/atorvastatin therapy represents such a solution. Usage of single-pill combinations is associated with $24 \%$ lower risk of the lack of compliance to treatment $^{22}$. A retrospective cohort study in a large managed-care population $(\mathrm{n}=8406)$ showed that patients who initiated therapy with both antihypertensive and lipid-lowering drugs within 30 days apart were more likely to be adherent to both drug regimens over time $^{23,24}$. It has been proven that the high level of patient compliance to treatment is related to $50 \%$ reduction of $\mathrm{CV}$ events ${ }^{24,25}$.

Treatment with the SPC of atorvastatin/amlodipine was generally well tolerated by our patients. Only nine of 243 (3.7\%) patients discontinued treatment, mostly for AE which were relatively rare, mildly to moderately manifested, and often transient. Swelling of lower extremities was the most common one, but compared to other studies with amlodipine its frequency was lower ${ }^{18-20,26-28}$. In the Gemini study, $4.8 \%$ of patients discontinued therapy due to $\mathrm{AE}^{18,26}$. In JEWEL 1 and 2 studies, the most common ones were peripheral edema (11.0\%), joint swelling (2.9\%) and headache (2.9\%), but only edema was linked to study treatment ${ }^{20}$. Similarly, in the CAPABLE clinical trial including 499 patients receiving drug therapy, com- mon treatment-related $\mathrm{AE}$ were peripheral edema (3.4\%) and headache $(2.2 \%)$, rarely myalgia and constipation $(2.0 \%)^{19}$.

It could be suggested that the lower rate of $\mathrm{AE}$ in our study was because of the use of amlodipine $5 \mathrm{mg}$ in the vast majority of patients (78.6\%), as well as the concomitant treatment with angiotensin-converting enzyme inhibitor or angiotensin II-receptor blocker (up to $84.8 \%$ ).

The main limitations of our study were as follows: 1) our research was designed as a prospective but not randomized and blinded study; 2) control group was not included - the effectiveness of the study medication was not compared to a placebo and/or other drug combination (free or SPC); and 3) the follow-up period was 3 months and conclusions on long-term efficacy and safety of the investigated SPC of atorvastatin/amlodipine could not be drawn.

In conclusion, treatment with the SPC of atorvastatin/amlodipine in our study was effective in reducing both blood pressure and lipid levels and generally well tolerated by patients with moderate to high risk.

\section{References}

1. Lozano R, Naghavi M, Foreman K, Lim S, Shibuya K, Aboyans $V$, et al. Global and regional mortality from 235 causes of death for 20 age groups in 1990 and 2010: a systematic analysis for the Global Burden of Disease Study 2010. Lancet. 2012;380:2095-212. doi: 10.1016/S0140-6736(12)61728-0.

2. Ezzati M, Lopez AD, Rodgers A, Vander Hoorn S, Murray CJ; Comparative Risk Assessment Collaborating Group. Selected major risk factors and global and regional burden of disease. Lancet. 2002;360:1347-60. doi: 10.1016/S0140-6736(02)11403-6.

3. Naydenov S, Torbova S, Nikolov F, Naydenova N. Abdominal obesity, arterial hypertension and diabetes mellitus in Bulgarian urban population. Bulg J Cardiol. 2013;2:15-24. doi: http:// bulgarianjournalofcardiology.blogspot.bg/p/blog-page_3.html.

4. Prugger C, Keil U, Wellmann J, de Bacquer D, de Backer G, Ambrosio GB, et al. Blood pressure control and knowledge of target blood pressure in coronary patients across Europe: results from the EUROASPIRE III survey. J Hypertens. 2011; 29:1641-8. doi: 10.1097/HJH.0b013e328348efa7.

5. Mancia G, Fagard R, Narkiewicz K, Redon J, Zanchetti A, Böhm M, et al. 2013 ESH/ESC Guidelines for the management of arterial hypertension: the Task Force for the management of arterial hypertension of the European Society of $\mathrm{Hy}_{-}$ pertension (ESH) and of the European Society of Cardiology (ESC). J Hypertens. 2013;31:1281-357. doi: 10.1097/01.hjh.0000431740.32696.cc. 
6. Chalmers J, Arima H, Harrap S, Touyz RM, Park JB. Global survey of current practice in management of hypertension as reported by societies affiliated with the International Society of Hypertension. J Hypertens. 2013;31:1043-8.

doi: 10.1097/HJH.0b013e32835f7eef.

7. Devabhaktuni M, Bangalore S. Fixed combination of amlodipine and atorvastatin in cardiovascular risk management: patient perspectives. Vasc Health Risk Manag. 2009;5:377-87. doi: https://doi.org/10.2147/VHRM.S3339.

8. Piepoli M, Hoes A, Agewall S, Albus Ch, Brotons C, Catapano A, et al. 2016 European Guidelines on cardiovascular disease prevention in clinical practice. Eur Heart J. 2016;37:2315-81. doi: 10.1093/eurheartj/ehw106.

9. Blaha M. The critical importance of risk score calibration. Time for transformative approach to risk score validation? J Am Coll Cardiol. 2016;67:2131-4. http://dx.doi.org/10.1016/j.jacc.2016.03.479.

10. Zeng R, Wang M, Zhang L. Is time an important problem in management of hypertension and hypercholesterolemia by using an amlodipine-atorvastatin single pill combination? Med Sci Monit. 2016;22:2648-55. doi: 10.12659/MSM.896843.

11. Gadzhanova S, Roughead E, Bartlett L. Long-term persistence to mono and combination therapies with angiotensin converting enzymes and angiotensin II receptor blockers in Australia. Eur J Clin Pharmacol. 2016;72:765-71. doi:10.1007/s00228-016-2037-x.

12. Schulz M, Krueger K, Schuessel K, Friedland K, Laufs U, Mueller W, et al. Medication adherence and persistence according to different antihypertensive drug classes: a retrospective cohort study of 255,500 patients. Int J Cardiol. 2016; 220:668-76. doi: 10.1016/j.ijcard.2016.06.263.

13. Chapman R, Benner J, Petrilla A, Tierce J, Collins S, Battleman $\mathrm{D}$, et al. Predictors of adherence with antihypertensive and lipid-lowering therapy. Arch Intern Med. 2005;165:1147-52. doi: 10.1001/archinte.165.10.1147.

14. Deedwania P, Shepherd J, Breazna A, DeMicco D. Effect of high-dose atorvastatin on the cardiovascular risk associated with individual components of metabolic syndrome: a subanalysis of the Treating to New Targets (TNT) study. Diabetes Obes Metab. 2016;18:56-63. doi: 10.1111/dom.12581.

15. Mason R. A rationale for combined therapy with a calcium channel blocker and a statin: evaluation of basic and clinical evidence. Curr Drug Targets Cardiovasc Haematol Disord. 2005;5:489-501. doi: https://www.ncbi.nlm.nih.gov/pubmed/ 16503869.

16. Paz M, De La Sierra A, Saez M, Barceló M, Rodríguez J, Castro S, et al. Treatment efficacy of anti-hypertensive drugs in monotherapy or combination: ATOM systematic review and meta-analysis of randomized clinical trials according to PRISMA statement. Medicine. 2016;95:30. doi: 10.1097/ MD.0000000000004071.

17. Kékes E. Combined antihypertensive and antilipemic therapy as one of the pillars in the poly-pharmacologic preventive strategy for patients with high cardiovascular risk. Orvosi Hetilap. 2008;149:1827-37. doi: 10.1556/OH.2008.28457.
18. Blank R, La Salle J, Reeves R, Maroni J, Tarasenko L, Sun F. Single-pill therapy in the treatment of concomitant hypertension and dyslipidemia (the Amlodipine/Atorvastatin Gemini Study). J Clin Hypertens (Greenwich). 2005;7:264-73. doi: 10.1111/j.1524-6175.2005.04533.x.

19. Flack J, Victor R, Watson K, Ferdinand K, Saunders E, Tarasenko L, et al. Improved attainment of blood pressure and cholesterol goals using single-pill amlodipine/atorvastatin in African Americans: the CAPABLE trial. Mayo Clin Proc. 2008;83:35-45. doi: https://doi.org/10.4065/83.1.35.

20. Hobbs F, Gensini G, Mancini G, Manolis A, Bauer B, Böhler $\mathrm{S}$, et al. Can combining different risk interventions into a single formulation contribute to improved cardiovascular disease risk reduction? Rationale and design for an international, open-label program to assess the effectiveness of a single pill (amlodipine/atorvastatin) to attain recommended target levels for blood pressure and lipids (The JEWEL Program). Int J Cardiol. 2006;16:242-50. doi: https://doi.org/10.1016/j.ijcard.2005.10.017.

21. Naydenov SN, Runev NM, Manov EI, Shabani RA, Donova TI. Lipid-lowering potency and tolerability of generic rosuvastatin in Bulgarian patients with high and very high risk. J Cardiovasc Dis Diagn. 2014;2:162-7. doi: http://dx.doi. org/10.4172/2329-9517.1000162.

22. Bašić Kes V, Jurašić M, Zavoreo I, Lisak M, Jeleč V, Matovina L. Age and gender differences in acute stroke hospital patients. Acta Clin Croat. 2016;55:69-78. doi: 10.20471/acc.2016.55.01.11.

23. Ettehad D, Emdin C, Kiran A, Anderson S, Callender Th, Emberson J, et al. Blood pressure lowering for prevention of cardiovascular disease and death: a systematic review and meta-analysis. Lancet. 2016;387:957-67. doi: https://doi.org/10.1016/ S0140-6736(15)01225-8.

24. Leibovitz E, Beniashvili M, Zimlichman R, Freiman A, Shargorodsky M, Gavish D. Treatments with amlodipine and atorvastatin have additive effect in improvement of arterial compliance in hypertensive hyperlipidemic patients. Am J Hypertens. 2003;16:715-8. doi: https://www.ncbi.nlm.nih.gov/pubmed/ 12944027.

25. Bangalore S, Kamalakkannan G, Parkar S, Messerli F. Fixeddose combinations improve medication compliance: a metaanalysis. Am J Med. 2007;120:713-9. doi: 10.1016/j.amjmed.2006.08.033.

26. Tomić M, Vrabec R, Poljičanin T, Ljubić S, Duvnjak L. Diabetic macular edema: traditional and novel treatment. Acta Clin Croat. 2017;56:124-32. doi: 10.20471/acc.2017.56.01.18

27. Boras V, Andabak-Rogulj A, Brailo V, Šimunković S, Gabrić $\mathrm{D}$, Vrdoljak D. Adverse drug reactions in the oral cavity. Acta Clin Croat. 2015;54:208-15. doi: http://actaclinica.eu/wordpress/wp-content/uploads/2016/08/13-Vucicevic-Acta-2.pdf

28. Preston R, Sun F, Tarasenko L. Safety and tolerability of coadministered amlodipine and atorvastatin in patients with concomitant hypertension and dyslipidemia in the RESPOND study. Am J Hypertens. 2005;18:92-3. doi: https://doi.org/ 10.1016/j.amjhyper.2005.03.258. 


\title{
Sažetak \\ UČINKOVITOST I SIGURNOST KOMBINACIJE ATORVASTATINA/AMLODIPINA
U JEDNOJ TABLETI KOD BOLESNIKA S ARTERIJSKOM HIPERTENZIJOM I DISLIPIDEMIOM
}

\author{
S. Naydenov Naydenov, N. Margaritov Runev, E. Ivanov Manov i S. Georgieva Torbova-Gigova
}

Cilj ovoga istraživanja je bio ocijeniti učinkovitost kombinacije atorvastatina/amlodipina u jednoj tableti kod bolesnika s arterijskom hipertenzijom, dislipidemijom i umjerenim do visokim kardiovaskularnim rizikom. Ovo prospektivno istraživanje obuhvatilo je 243 bolesnika s arterijskom hipertenzijom, dislipidemijom i umjerenim do visokim kardiovaskularnim rizikom, srednje dobi od $63,3 \pm 9,8$ godina. Bolesnicima je propisana terapija jednim od sljedećih režima doziranja kombinacije atorvastatina/amlodipina u jednoj tableti: 10/5,10/10, 20/5 ili 20/10 mg na dan. Razdoblje praćenja bilo je 3 mjeseca.

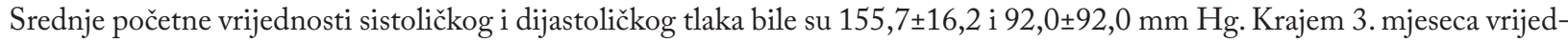

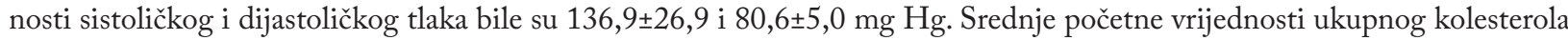
i kolesterola niske gustoće bile su 6,6 $\pm 1,2$ i 4,4 $\pm 1,1 \mathrm{mmol} / \mathrm{L}$. Krajem 3. mjeseca vrijednosti ukupnog kolesterola i kolesterola

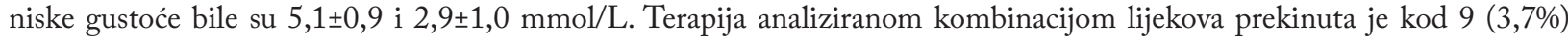
bolesnika zbog neželjenih nuspojava. U zaključku, terapija kombinacijom atorvastatina/amlodipina u jednoj tableti visoko je učinkovita i dobro ju podnose bolesnici s arterijskom hipertenzijom, dislipidemijom i umjerenim do visokim kardiovaskularnim rizikom.

Ključne riječi: Hipertenzija; Dislipidemije; Kardiovaskularne bolesti; Antibipertonici 